\title{
NOVI NAČIN OBRAČUNA KRITIČNOG BROJA JAJNIH LEGALA GUBARA (LYMANTRIA DISPAR L.) U SVRHU BOLJE PROGNOZE POPULACIJE
}

\section{NEW CALCULATION OF CRITICAL NUMBER OF GYPSY MOTH (LYMANTRIA DISPAR L.) EGG MASSES FOR BETTER POPULATION DENSITY PROGNOSIS}

\author{
Milan PERNEK
}

\section{Sažetak:}

Gubar (Lymantria dispar) je kao štetnik hrastovih šuma u Hrvatskoj dominirao do 60-tih godina prošloga stoljeća, otkada su njegove populacije u kontinentalnom dijelu u blagom opadanju, sa cikličkim gradacijama svakih 10-11 godina. Zadnje dvije gradacije zabilježene su 2003-2005 i 2013-2014 godine. U radu se opisuje nov način obračuna kritičnog broja jajnih legala gubara, kojim se procjenjuje rizik golobrsta ključan u praktičnom šumarstvu za donošenje odluke o suzbijanju. Nov način obračuna iskazuje kritične brojeve kao broj jajnih legala po hektaru, za razliku od dosadašnjeg koji se temeljio na broju stabala na kojemu se nalazi barem jajno leglo i prikazivao se kao postotak zaraze. Postotak zaraze dijelio je rizik golobrsta u pet klasa, pri čemu je kritična Klasa 5 predstavljala zaraženost više od 50\% stabala. Dosadašnjim obračunom nije se uzimala u obzir starost stabla, iako je ona povezana s veličinom krošnje, odnosno količinom lišća. Nadalje nije uziman u obzir broj jaja u jajnom leglu. Nov obračun bazira se na broju gusjenica koje imaju potencijal obrstiti stablo hrasta određene starosti dobiven iz podataka iz literature. Preračunavanjem tih ulaznih podataka korištenjem prosječnog broja jaja u jednom jajnom leglu gubara, koji je dobiven iz 50 uzoraka jajnih legala, te normale koja definira broj stabla hrasta lužnjaka po hektaru, dobivena je formula koji izračunava kritični broj jajnih legala gubara po hektaru. Na osnovi tih rezultata formirane su tri 3 kategorije rizika temeljene na broju gusjenica koji obrste stablo određene starosti. Svaka od njih različito definira potrebu za suzbijanje gubara: Kategorija I- treba tretirati, Kategorija II- iznimno tretirati uz specifičan razlog i Kategorija III ne treba tretirati. Kritična Kategorija I uspoređena je s Klasom 5, odnosno Kategorija II s Klasom IV na podacima iz gradacije 2004. i 2013. godine.

Rezultati ukazuju kako je primjenom novog obračuna trošak suzbijanja smanjen za $25 \%$. Uz evidentne prednosti ipak su i u novom obračunu uočene slabosti vezane uz nepoznavanje nekoliko važnih varijabli: stvarni broj stabala po hektaru i stvarni broj intaktnih gusjenica koji se dobiva oduzimanjem parazitiranih i sterilnih jaja od prosječnog broja jaja u leglu. Još jedna slabo poznata varijabla prosječna količina lišća koju jedna gusjenica može obrstiti te količinu lišća u krošnji hrastova određene starosti koju treba u budućim istraživanjima kvalitetnije definirati.

KLJUČNE RIJEČI: populacijska dinamika, suzbijanje štetnika, hrast lužnjak, Quercus robur. 


\section{UVOD}

\section{INTRODUCTION}

Gubar- Lymantria dispar L. (Lepidoptera, Erebidae) je polifagni štetnik koji u vrijeme masovne pojave može obrstiti šume na vrlo velikim površinama. Kao štetnik u hrastovim šumama u Hrvatskoj je dominirao do 60-tih godina prošloga stoljeća. Nakon tog razdoblja pojačano se pojavljuju i drugi defolijatori kao primjerice mrazovci i hrastova osa listarica (Hrašovec i Harapin, 1999). U 2013. godini, osim u hrastovim sastojinama, bilježi se gradacija gubara u bukovim sastojinama, na području Siska i Petrinje (IPP-Hrvatski šumarski institut, Izvještajno prognozni poslovi).

Kako je gubar jedan od najznačajnijih primarnih štetnika hrastovih sastojina, o njemu treba voditi brigu kako bi se izbjegle velike štete nakon golobrsta (Hrašovec i Harapin 1999). One se mogu podijeliti na izravne - vezane uz gubitak drvne mase i neizravne - vezane za slabljenje vitaliteta stabala i njihove otpornosti na druge štetne organizme (Lobinger i Skatulla, 1998; Hrašovec i Harapin 1999). O gubitku prirasta nakon golobrsta pišu Klepaci i Spaić (1965) te Klepac (1966), koji su utvrdili da defolijacija gusjenica gubara u hrastovim šumama dovodi do $30 \%$, pa čak i $40 \%$ gubitka prirasta, iz čega se lako može obračunati visok financijski gubitak. Neizravne štete ili pitanje na koji način se stvara sinergijski nepovoljni učinak dva ili više golobrsta za redom nije do sada detaljno proučavano u Hrvatskoj. U jednoj studiji u Bavarskoj (Lobinger i Skatulla, 1998) zaključeno je kako su dva uzastopna golobrsta za hrastove šume pogubna, jer je količina sušaca u šumi nakon toga iznosila $50 \%$. Zbog ponovnog listanja nakon golobrsta svako pojedinačna stablo troši rezerve, zbog čega slabi otpornost na sekundarne štetne organizme. U tom kontekstu često se spominju sekundarni štetnici, gdje prednjači hrastov krasnik, Agrilus biguttatus Fab. (Wuff i Kehr, 1996; Moraal i Hilszczanski, 2000).

U Hrvatskoj se jači intenziteti napada gubara javljaju svakih 10-11 godina (Pernek i Pilaš, 2005; Pernek i dr., 2008), a posljednje dvije gradacije zabilježene su 2003-2005. te 2013-2014. godine (IPP). Za praktično šumarstvo vrlo je važno redovito praćenje (monitoring) i prognoza fluktuacije gubareve populacije, koja treba služiti pravovremenoj pripremi i organizaciji zaštitnih mjera. Stoga se jednom godišnje obilaze sastojine i prati broj jajnih legala iz kojih se obračunavaju kritični brojevi, koji predstavljaju rizik golobrsta odnosno uvjetuju odluku o provođenju ili ne provođenju zaštitnih mjera.

U hrvatskom -mediteranskom području, gubar ima drukačije zakonitosti, pa tako jači napadi dolaze svakih nekoliko godina bez jasno izraženog periodiciteta (Lacković i dr., 2015). Brst gusjenica se u tom području javlja na različitim vrstama hrastova (Quercus ilex L., Q. cerris L., Q. pubescens Willd.), a s obzirom na gospodarske ciljeve štetnost nije vezana uz gospodarenje šuma već uz njihovu zaštitnu funkciju.
Bez obzira na golobrst čini se da je reakcija prirodnih neprijatelja u tom području vrlo brza i učinkovita, tako da dolazi do sloma populacija, pa nema uzastopnih golobrsta pa ni sušenja šuma (Lacković i dr. 2016). Obračun rizika golobrsta objašnjen u ovom radu ne odnosi se na mediteransko područje, niti ima ciljani praktični značaj za to područje.

Do sada se u praćenju gubarovih gradacija koristila metodologija brojanja jajnih legala, kojim se dolazi do izračuna kritičnog broja odnosno praga kada će se i gdje koristiti mjere zaštite (Vasić, 1981 ). Kritični broj tako je baza za sprječavanja golobrsta, odnosno za više ili niže troškove suzbijanja, pa čak i potrebnog ili nepotrebnog suzbijanja. Stoga o kritičnim brojevima treba voditi posebno računa. Bez obzira na tu činjenicu, iznenađujuće je da istraživanja o kritičnim brojevima gubara zadnjih 30 godina manjkaju. Uz te činjenice, aktualnu metodologiju (Vasić, 1981) treba smatrati zastarjelom s obzirom na sve promijene koje su se dogodile u šumarstvu, gdje se posebno ističu način gospodarenja i klimatske promjene. Novije studije tako opisuju promjenu u veličinama krošanja zadnjih 30 godina u sastojinama iste starosti (Dubravac i dr., 2009). To praktično znači da se promijenila količina lišća u krošnji, a time i potencijal za golobrst defolijatora i posljedično postavlja pitanje upotrebljivosti tako obračunatih kritičnih brojeva.

Važeći obračun kritičnih brojeva u Hrvatskoj radi se po metodici opisanoj u Vasić (1981), Pernek (2001) i Pernek i Pilaš (2005), a koja se primjenjivala u praksi više od 30 godina.

Sama metoda generalno daje prihvatljivu sliku dinamike populacija gubara. Nedostaci u pogledu pravilnog uzorkovanja i interpretacije podataka su evidentni, jer taj obračun ne uzima u obzir varijable koje imaju izravan i ključan utjecaj na brštenje, a to su broj gusjenica u sastojini i količina lišća koje gusjenicama stoje na raspolaganju. Stoga takav način obračuna daje vrlo općenitu sliku broja legala u sastojini, a pogreške u procjeni su neizbježne. Obračun intenziteta napada dobiva se tako da se broj stabala u odjelu na kojima je nađeno barem jedno leglo dijeli s ukupnim brojem pregledanih stabala. Takav intenzitet se iskazivao u postotku i kategorizirao u klase napada poredane u 5 kategorija: < 1\% (klasa 1); 1-5\% (klasa 2); 5-20\% (klasa 3), 20-50\% (klasa 4), >50\% (klasa 5). Primjerice za 80 godina stari hrast lužnjak (Quercus robur L.) prema studiji Tropina (1962) kritično se smatra 2.200 gusjenica gubara, što znači oko 4 jajna legla po stablu. Prema dosadašnjem obračunu kritično je stablo na kojemu je barem 1 leglo, jer predstavlja zarazu od $100 \%$. Pretpostavi li se da u jednoj 80 -godišnjoj sastojini hrasta lužnjaka ima prosječno 1 jajno leglo po stablu, takva sastojina je raspoređena u klasu $5 \mathrm{i}$ obavezno se predviđalo tretiranje. Prema spomenutoj studiji (Tropin, 1962) jačeg brsta ne treba očekivati, stoga tretiranje sastojine iz navedenog primjera predstavlja nepotrebno trošenje resursa i nepotreban rizik ugrožavanja populacija neciljanih organi- 
zama. Kako su šume u Hrvatskoj većim dijelom FSC certificirane, jedina opcija je korištenje biološkog sredstva u suzbijanju što znatno poskupljuje tretiranje zrakoplovima kada je ono potrebno. Iz svega toga opravdano je postaviti pitanje ; da li je izračunati kritični broj zadovoljavajuće precizan s obzirom na velike troškove suzbijanja, te da li se troškovi suzbijanja mogu sniziti boljim planiranjem na temelju što preciznijeg obračuna kritičnog broja jajnih legala gubara?

Cilj ovog rada je, na temelju podataka iz literature, izračunati kritične brojeve jajnih legala gubara na nov način, uzimajući u obzir broj gusjenica po jednom leglu, starost sastojine, parazitiranost i broj stabala po ha. Svrha je dobiti bolju metodu obračuna kritičnog broja primjenjivu u praksi, što će imati izravan utjecaj na manje korištenje insekticida uz financijske uštede. Također su financijski učinci novog načina obračuna, pa time i površinama obuhvaćene tretiranjem uspoređeni sa starima, kako bi se vidjelo da li se trošak suzbijanja smanjuje uz isti rezultat suzbijanja.

\section{METODA RADA}

\section{WORKING METHODS}

Izračun kritičnih brojeva $(\mathrm{KB})$ gusjenica u ovom radu predstavlja broj gusjenica po jedinici površine (ha) koji će najvećim dijelom obrstiti krošnju i odnosi se isključivo na hrast lužnjak. Za obračun kritičnog broja trebaju podaci o količini lišća, broju zdravih gusjenica i količini lišća koju 1 gusjenica prosječno konzumira od izlaska iz jaja do kukuljenja. Kako su ti podaci sastojinski varijabilni, obračun bi se trebao raditi za svaku sastojinu posebno. Kako bi se to izbjeglo, stvoren je model temeljen na podacima iz literature:

i) Tropin (1962) - Broj gusjenica koji će obrstiti stablo određene starosti (indirektna veza s prosječnom količinom lišća koju pojede jedna gusjenica od eklozije do kukuljenja)

ii) Bezak (1992) - Normale hrasta lužnjaka (broj stabala po jedinici površine)

Kratice koje se koriste u radu su sljedeće:

$\mathbf{K B}_{\mathrm{JL}}$ - kritični broj jajnih legala za 1 stablo hrasta preračunato prema Tropin (1962) na temelju 500 jaja u leglu

$\mathbf{K B}_{\mathrm{IL}}$ - Critical number of egg masses per 1 oak tree calculated according to Tropin (1962) on the basis of 500 eggs per egg mass

$\mathbf{K B}_{\mathrm{g}}-$ kritični broj gusjenica za 1 stablo hrasta prema Tropin (1962)

$\mathbf{K B}_{\mathbf{g}}-$ Critical number of larvae per 1 oak tree according to Tropin (1962)

Podaci o zarazi gubara u Hrvatskoj za 2004 i 2013. godinu (gradacije) dobiveni su iz službenih podataka Izvještajno prognoznih poslova (IPP) u šumarstvu koje provodi $\mathrm{Hr}$ - vatski šumarski institut, koji su sakupljeni terenskim opažanjem i registracijom broja jajnih legla na terenu metodom transekta (Vasić, 1981; Pernek, 2001; Pernek i Pilaš, 2005).

Za potrebe izračuna prosječnog broja gusjenica u jajnom leglu u laboratorij Hrvatskog šumarskog instituta, Jastrebarsko, 15.1.2013. doneseno je 50 jajnih legala gubara s nekoliko lokacija iz Uprave šuma podružnica Nova Gradiška, gdje su legla nasumično odabrana na transektu sjever-jug i međusobnoj udaljenosti od $50 \mathrm{~m}$, prvo sa sjeverne, zatim zapadne, istočne i južne strane te istim redoslijedom u nastavku. Jajna legla su stavljena u petrijeve posude, te su prvo s njih oprezno skinute dlačice, a zatim su jajašca pregledana pod stereomikroskopom i svrstavana u skupine: vitalna, sterilna i parazitirana, te nakon toga izbrojana.

Obračuni kritičnih brojeva za 2004. i 2013. godinu dobiveni su iz službenih podataka Izvještajno prognoznih poslova u šumarstvu Hrvatskog šumarskog instituta.

\section{REZULTATI}

RESULTS

$\mathrm{Na}$ temelju ulaznih podataka normale i kritičnog broja gusjenica za 1 stablo hrasta lužnjaka izračunat je kritični broj jajnih legala gubara za 1 stablo (Tablica 1). Da bi taj podatak bio ispravan mora biti poznato koliko vitalnih jaja ima u jajnom leglu. Brojanjem jaja iz 50 legala, u jednom jajnom leglu gubara bilo je najmanje 136, a najviše 975 jaja, što je prosječno $511 \pm 204$ jaja (Tablica 2).

Na temelju tog rezultata, a za potrebe istraživanja kritičnog broja jajnih legala gubara po hektaru, broj jaja u 1 jajnom leglu aproksimiran je sa 500 i služi kao baza za obračun najveće kategorije rizika nazvana Kategorija I. Kako je iz rezultata vidljivo postoji velika standardna devijacija broja jaja u leglu te je zbog toga formirana Kategorija II na bazi 700 jaja u 1 jajnom leglu. Kategorija II formirana je iz sigurnosnih razloga radi moguće oscilacije varijabli, kao što su broj jaja u jajnom leglu, ali i odstupanje od normale. Prve dvije klase formirane su sa stanovitim faktorom sigurnosti, jer nije obračunata parazitiranost, koja je iznosila u ovom istraživanju prosječno $23,7 \%$ (Tablica 2). Takav faktor sigurnosti je stvoren kako ne bi došlo do velikih pogrešaka u odlukama o tretiranju, pri čemu Kategorija I označava rizik golobrsta odnosno odluku da se sastojina tretira, a Kategorija II mali rizik od golobrsta odnosno dodatnu provjeru ili planiranje tretiranja zbog nekog specifičnog razloga (zaštićeni objekt, jako narušeno zdravstveno stanje sastojine i sl.). Kategorija III označava da nema rizika od golobrsta te se za sastojine koje se nalaze u toj kategoriji može donijeti odluka da tretiranje nije potrebno.

$\mathrm{Na}$ temelju dobivenih podataka kritični broj jajnih legala po hektaru neke sastojine n-te starosti može se prikazati kao jednadžba: 


$$
\mathrm{KB}_{\text {IL(n) }} / \mathrm{ha}=\mathrm{KB}_{\text {JL(n) }} / \text { stablo } \times \text { Normala }_{(\mathrm{dr})}
$$

Vrijednosti $\mathrm{KB}_{\mathrm{IL}} \mathrm{za}$-starost sastojine prikazane su u Tablici 1. Vrijednosti jednake ili veće od $\mathrm{KB}_{\mathrm{IL}}$ smatra se kritičnim i stavlja u Kategoriju I. Kada bi broj jaja u 1 jajnom leglu bio $20 \%$ veći, apsolutni broj bio bi 700 . Zbog toga se za obračun Kategorije II uzima $\mathrm{KB}_{\mathrm{IL}}$ izračunat na temelju 700 jaja u jajnom leglu. Vrijednosti veće od 700 jaja spadaju u Kategoriju III (Tablica 3)

Prikazani kritični brojevi vrijede samo za hrast lužnjak, dok bi za ostale vrste trebalo napraviti nove obračune. Važno je naglasiti da kritični brojevi prikazani u Tablici 3 predstav- ljaju idealizirane vrijednosti temeljene na broju jaja u leglu $=500$ i normale po dobnim razredima iz ranijih istraživanja (Bezak 1992). Treba naglasiti da za potrebe ovog istraživanja i u tretiranjima u 2013. godini, nikakva korekcija nije korištena. U nastavku se prikazuje kako bi se podaci dobiveni na terenu uvrstili u neku od kategorija potrebno je napraviti korekciju na način da se broj legala po ha pomnoži sa korekcijskim faktorom (kf) koji uzima u obzir stvarni broj stabala po ha i stvarni broj jaja u jajnom leglu. Stoga se broj jajnih legala po ha mora pomnožiti sa kf kojeg dobiva iz jednadžbe:

Tablica 1. Kritični brojevi jajnih legala po ha izračunati iz kritičnih brojeva gusjenica gubara za stablo hrasta lužnjaka (KBg)određene starosti (prema Tropin (1962) i normale hrasta lužnjaka prema Bezak (1992)

Table 1 Critical numbers of gypsy moth egg masses per ha calculated by critical numbers of larvae per peduncle oak tree (KBg) of different age (according to Tropin (1962) and Normal distribution of peduncule oak according to Bezak (1992)

\begin{tabular}{|c|c|c|c|c|}
\hline $\begin{array}{l}\text { Starost hrasta } \\
\text { Age of oak tree }\end{array}$ & $\begin{array}{c}\text { Normala/ha } \\
\text { Normal distribution /ha }\end{array}$ & $\begin{array}{l}\mathrm{KB}_{\mathrm{g}} / \text { stablo } \\
\mathrm{KB}_{\mathrm{g}} / \text { tree }\end{array}$ & $\mathrm{KB}_{\mathrm{JL}}$ / stablo $\mathrm{KB}_{\mathrm{JL}} /$ tree & $\begin{array}{l}\mathrm{KB}_{\mathrm{J} / \mathrm{ha}} \\
\mathrm{KB}_{\mathrm{Jl}} / \mathrm{ha}\end{array}$ \\
\hline 20 & 2428 & 350 & 0,7 & 1700 \\
\hline 30 & 1342 & 550 & 1,1 & 1476 \\
\hline 40 & 829 & 800 & 1,6 & 1326 \\
\hline 50 & 569 & 1000 & 2,0 & 1138 \\
\hline 60 & 419 & 1300 & 2,6 & 1089 \\
\hline 70 & 325 & 1700 & 3,4 & 1105 \\
\hline 80 & 260 & 2200 & 4,4 & 1144 \\
\hline 90 & 213 & 2800 & 5,6 & 1193 \\
\hline 100 & 177 & 3300 & 6,6 & 1168 \\
\hline 110 & 150 & 3300 & 6,6 & 990 \\
\hline 120 & 128 & 3300 & 6,6 & 845 \\
\hline
\end{tabular}

Tablica 2. Broj jaja u uzorkovanim jajnim leglima gubara i postotak parazitiranosti (u zagradama)

Table 2 Number of eggs in sampled gypsy moth egg masses and their respective parasitism rate (in brackets)

\begin{tabular}{|c|c|c|c|c|c|c|c|c|c|}
\hline $\begin{array}{l}\text { Uzorak } \\
\text { Sample }\end{array}$ & $\begin{array}{l}\text { n jaja } \\
n \text { eggs }\end{array}$ & $\begin{array}{l}\text { Uzorak } \\
\text { Sample }\end{array}$ & $\begin{array}{l}\text { n jaja } \\
n \text { eggs }\end{array}$ & $\begin{array}{l}\text { Uzorak } \\
\text { Sample }\end{array}$ & $\begin{array}{c}n \text { jaja } \\
n \text { eggs }\end{array}$ & $\begin{array}{l}\text { Uzorak } \\
\text { Sample }\end{array}$ & $\begin{array}{l}n \text { jaja } \\
n \text { eggs }\end{array}$ & $\begin{array}{l}\text { Uzorak } \\
\text { Sample }\end{array}$ & $\begin{array}{c}n \text { jaja } \\
n \text { eggs }\end{array}$ \\
\hline 1 & $\begin{array}{c}615 \\
(3,1)\end{array}$ & 11 & $\begin{array}{l}625 \\
(7,0)\end{array}$ & 21 & $\begin{array}{c}490 \\
(18,0)\end{array}$ & 31 & $\begin{array}{c}220 \\
(75,0)\end{array}$ & 41 & $\begin{array}{c}587 \\
(22,5)\end{array}$ \\
\hline 2 & $\begin{array}{c}386 \\
(32,6)\end{array}$ & 12 & $\begin{array}{c}328 \\
(26,8)\end{array}$ & 22 & $\begin{array}{c}777 \\
(20,3)\end{array}$ & 32 & $\begin{array}{c}533 \\
(18,2)\end{array}$ & 42 & $\begin{array}{c}635 \\
(16,1)\end{array}$ \\
\hline 3 & $\begin{array}{c}637 \\
(6,1)\end{array}$ & 13 & $\begin{array}{c}295 \\
(13,2)\end{array}$ & 23 & $\begin{array}{c}395 \\
(78,7)\end{array}$ & 33 & $\begin{array}{c}290 \\
(24,5)\end{array}$ & 43 & $\begin{array}{c}181 \\
(8,8)\end{array}$ \\
\hline 4 & $\begin{array}{c}426 \\
(12,0)\end{array}$ & 14 & $\begin{array}{l}458 \\
(7,6)\end{array}$ & 24 & $\begin{array}{c}188 \\
(89,9)\end{array}$ & 34 & $\begin{array}{c}711 \\
(10,7)\end{array}$ & 44 & $\begin{array}{c}136^{*} \\
(75,0)\end{array}$ \\
\hline 5 & $\begin{array}{c}656 \\
(14,5)\end{array}$ & 15 & $\begin{array}{c}840 \\
(7,7)\end{array}$ & 25 & $\begin{array}{c}187 \\
(5,9)\end{array}$ & 35 & $\begin{array}{c}262 \\
(25,6)\end{array}$ & 45 & $\begin{array}{c}218 \\
(47,2)\end{array}$ \\
\hline 6 & $\begin{array}{c}544 \\
(12,9)\end{array}$ & 16 & $\begin{array}{c}668 \\
(15,3)\end{array}$ & 26 & $\begin{array}{c}865 \\
(5,9)\end{array}$ & 36 & $\begin{array}{c}490 \\
(41,0)\end{array}$ & 46 & $\begin{array}{c}489 \\
(9,0)\end{array}$ \\
\hline 7 & $\begin{array}{c}497 \\
(18,3)\end{array}$ & 17 & $\begin{array}{l}629 \\
(4,9)\end{array}$ & 27 & $\begin{array}{l}544 \\
(3,3)\end{array}$ & 37 & $\begin{array}{c}600 \\
(1,3)\end{array}$ & 47 & $\begin{array}{c}360 \\
(13,6)\end{array}$ \\
\hline 8 & $\begin{array}{c}677 \\
(14,8)\end{array}$ & 18 & $\begin{array}{c}744 \\
(1,3)\end{array}$ & 28 & $\begin{array}{c}820 \\
(6,3)\end{array}$ & 38 & $\begin{array}{c}710 \\
(45,4)\end{array}$ & 48 & $\begin{array}{c}594 \\
(22,2)\end{array}$ \\
\hline 9 & $\begin{array}{c}975^{* *} \\
(6,9)\end{array}$ & 19 & $\begin{array}{c}462 \\
(27,1)\end{array}$ & 29 & $\begin{array}{c}271 \\
(61,3)\end{array}$ & 39 & $\begin{array}{c}339 \\
(14,5)\end{array}$ & 49 & $\begin{array}{c}562 \\
(9,8)\end{array}$ \\
\hline 10 & $\begin{array}{c}538 \\
(23,2)\end{array}$ & 20 & $\begin{array}{c}783 \\
(8,0)\end{array}$ & 30 & $\begin{array}{c}323 \\
(77,1)\end{array}$ & 40 & $\begin{array}{c}655 \\
(18,6)\end{array}$ & 50 & $\begin{array}{c}355 \\
(54,6)\end{array}$ \\
\hline
\end{tabular}

*najmanji broj jaja u 1 jajnom leglu gubara (least number of eggs in one egg mass)

**najveći broj jaja u 1 jajnom leglu gubara (largest number of eggs in one egg mass) 
Tablica 3. Brojevi jajnih legala gubara po hektaru prikazani po rizičnim klasama i starosti sastojine

Table 3 Number of gypsy moth egg masses per ha according to risk classes and forest age

\begin{tabular}{|c|c|c|c|}
\hline \multirow{2}{*}{$\begin{array}{c}\text { Starost } \\
\text { Age }\end{array}$} & \multicolumn{3}{|c|}{$\begin{array}{l}\mathrm{KB}_{\mathrm{JL}} / \mathrm{ha} \\
\mathrm{KB}_{\mathrm{JL}} / \mathrm{ha} \\
\end{array}$} \\
\hline & Klasa I - Class I & Klasa II - Class II & Klasa III - Class III \\
\hline 20 & $>1701$ & $1214-1700$ & $<1214$ \\
\hline 30 & $>1401$ & $1054-1400$ & $<1054$ \\
\hline 40 & $>1301$ & $947-1300$ & $<947$ \\
\hline 50 & $>1101$ & $778-1100$ & $<778$ \\
\hline 60 & $>1101$ & $813-1100$ & $<813$ \\
\hline 70 & $>1101$ & $789-1100$ & $<789$ \\
\hline 80 & $>1101$ & $817-1100$ & $<817$ \\
\hline 90 & $>1151$ & $852-1150$ & $<852$ \\
\hline 100 & $>1151$ & $834-1150$ & $<834$ \\
\hline 110 & $>951$ & $707-950$ & $<707$ \\
\hline 120 & $>801$ & $603-800$ & $<603$ \\
\hline
\end{tabular}

\section{$\mathrm{kf}=\mathrm{N} /$ Normala $\mathrm{x}$ njl/500}

Pri čemu su:

$\mathrm{N}$ - stvarni broj stabla po ha (real number of trees per ha) Normala - broj stabala po ha za određeni dobni razred prema Bezak 1992 (number of trees per ha according to Bezak 1992)

$\mathrm{Njl} \mathrm{-} \mathrm{stvarni} \mathrm{broj} \mathrm{jaja} \mathrm{u} \mathrm{jajnom} \mathrm{leglu} \mathrm{(real} \mathrm{number} \mathrm{of} \mathrm{eggs} \mathrm{in}$ one egg mass)

Tretiranja u 2013. godini provedena su bez korekcije kf iz praktičnih razloga. Ukoliko se kf uzme u obzir, vidljive su dodatne uštede (Tablice 3).

U 2004. godini je tako ukupno pregledano 175.864,00 ha, a u 2013. ukupno $167.782,44$ ha hrastovih i bukovih sastojina. U Tablici 4. i Tablici 5. prikazane su razlike u rezultatima obračuna kritičnog broja gubara. U Kategoriji I i Klasi

Tablica 4. Razlika u rezultatima obračuna kritičnih brojeva u 2004. godini

Table 4 Differences between calculated critical numbers in 2004

\begin{tabular}{|c|c|c|c|c|c|c|c|c|}
\hline \multirow[b]{2}{*}{ Područje - Area } & \multicolumn{3}{|c|}{$\begin{array}{c}\left.\text { Kategorija (KB } \mathrm{KB}_{\mathrm{J}} / \mathrm{ha}\right) \\
\text { (Novi obračun) - (New calculation) }\end{array}$} & \multicolumn{5}{|c|}{$\begin{array}{c}\text { Klase napada } \\
\text { (Stari obračun) - (Old calculation) } \\
\end{array}$} \\
\hline & 1 & II & III & $50 \leq$ & $20-50$ & $5-20$ & $1-5$ & $1 \geq$ \\
\hline BJELOVAR & 0 & 0 & $12.620,00$ & 0 & 62,00 & 597,00 & 5020,00 & 6941,00 \\
\hline KARLOVAC & 0 & 0 & $4.034,00$ & 0 & 37,00 & 360,00 & 700,00 & $2.937,00$ \\
\hline KOPRIVNICA & 0 & 0 & $4.849,00$ & 0 & 0,00 & 714,00 & $1.497,00$ & $2.638,00$ \\
\hline NAŠICE & 923,00 & 405,00 & $19.249,00$ & $1.061,00$ & $2.129,00$ & $4.350,00$ & $4.250,00$ & $8.787,00$ \\
\hline NOVA GRADIŠKA & $1.809,00$ & 758,00 & $9.858,00$ & $1.857,00$ & $1.915,00$ & $3.176,00$ & $1.571,00$ & $3.906,00$ \\
\hline OSIJEK & $2.852,00$ & 752,00 & $13.768,00$ & $1.754,00$ & $3.291,00$ & $3.033,00$ & $5.219,00$ & $4.075,00$ \\
\hline POŽEGA & $1.240,00$ & $5.34,00$ & $9.100,00$ & $1.604,00$ & $2.075,00$ & $3.349,00$ & $2.424,00$ & $1.422,00$ \\
\hline SISAK & $5.377,00$ & $2.083,00$ & $4.026,00$ & $6.985,00$ & $1.447,00$ & $1.090,00$ & 225,00 & $1.739,00$ \\
\hline VINKOVCI & $3.146,00$ & $1.683,00$ & $60.450,00$ & $4.689,00$ & 3745,00 & $3.773,00$ & $9.668,00$ & $43.404,00$ \\
\hline ZAGREB & 479,00 & 148,00 & $15.721,00$ & 758,00 & 631,00 & $2.250,00$ & $5.293,00$ & $7.416,00$ \\
\hline UKUPNO & $15.826,00$ & $6.363,00$ & $153.675,00$ & $18.708,00$ & $15.332,00$ & $22.692,00$ & $35.867,00$ & $83.265,00$ \\
\hline
\end{tabular}

Tablica 5. Razlika u rezultatima obračuna kritičnih brojeva u 2013. godini

Table 5 Differences between calculated critical numbers in 2013

\begin{tabular}{|c|c|c|c|c|c|c|c|c|}
\hline \multirow[b]{2}{*}{ Područje - Area } & \multicolumn{3}{|c|}{$\begin{array}{c}\text { Kategorija (KB, } / \text { ha) } \\
\text { (Novi obračun) - (New calculation) }\end{array}$} & \multicolumn{5}{|c|}{$\begin{array}{c}\text { Klase napada } \\
\text { (Stari obračun) - (Old calculation) }\end{array}$} \\
\hline & 1 & II & III & $50 \leq$ & $20-50$ & $5-20$ & $1-5$ & $1 \geq$ \\
\hline BJELOVAR & 515,60 & 93,27 & $10.527,11$ & 629,43 & 234,01 & 861,36 & $4.525,5$ & $4.885,68$ \\
\hline KARLOVAC & 0 & 0 & $3.619,00$ & 0 & 58,00 & 382,00 & 776,00 & $2.403,00$ \\
\hline KOPRIVNICA & 0 & 0 & $3.815,31$ & 0 & 0 & 584,65 & 740,28 & $2.490,38$ \\
\hline NAŠICE & $3.957,00$ & 973,00 & $17.405,00$ & $3.367,00$ & $2.773,00$ & 2742,00 & 3541,00 & 9912,00 \\
\hline NOVA GRADIŠKA & $5.911,95$ & 758,77 & $5.736,81$ & 5598,76 & $1.666,05$ & $1.657,24$ & $1.102,76$ & $2.382,72$ \\
\hline OSIJEK & 215,91 & 229,39 & $17.500,08$ & 293,90 & $1.324,68$ & $3.011,57$ & $6.609,77$ & $6.705,46$ \\
\hline POŽEGA & $1.852,28$ & 465,38 & $8.445,75$ & $2.286,41$ & $1.433,94$ & $2.932,09$ & $2.686,79$ & $1.424,18$ \\
\hline SISAK & $7.840,61$ & $2.007,69$ & $3.921,11$ & 9492,36 & $1.741,41$ & 852,62 & 264,1 & $1.418,92$ \\
\hline VINKOVCI & 0 & 0 & $55.819,05$ & 0 & 42,75 & $4.144,78$ & $13.362,43$ & $38.269,09$ \\
\hline ZAGREB & 956,57 & 277,45 & $14.938,35$ & $1.346,86$ & 562,85 & $2.200,21$ & $6.082,18$ & $5.980,27$ \\
\hline UKUPNO & $21.249,92$ & $4.804,95$ & $141.727,57$ & $23.014,72$ & $9.836,69$ & $19.368,52$ & $39.690,81$ & $75.871,7$ \\
\hline
\end{tabular}


50\% koje označavaju obavezno suzbijanje razlika je u 2004. godini iznosila 2.882,ha, a u 2013. 1.764,80ha (Tablica 4. i 5.). Još veća razlika vidljiva je u Kategoriji II odnosno Klase 20-30\%, gdje je u 2004. g. razlika bila 8.969,00 ha, a 2013. g 5.031,74 ha (Tablica 4. i 5.).

\section{RASPRAVA DISSCUSION}

Usporedbom kritičnih brojeva u kritičnoj Kategoriji I i Klasi 5 , postoji jasna razlika definiranih površina predviđenih za tretiranje i iznosila je u 2004. godini 2.882 ha, odnosno 1.775 ha u 2013. godini. Područja različitih Kategorija ili Klasa često međusobno graniče, ili se dogodi da niža kategorija ili klasa bude uklopljena sa višom. U takvim slučajevima niža kategorija ili klasa ne izdvaja se iz suzbijanja. Uz to praksa je da se dio II Kategorije ili IV Klase, stavi u plan tretiranja za što postoji više razloga. Najčešći je razlog taj da je šuma slabog vitaliteta ili je iz nekog razloga zaštićena. U 2013. godini tako je prskano ukupno 26.914 ha (izvor: Darko Pleskalt, Hrvatske šume) što znači da je uz kritičnu I Kategoriju prskana i II kategorija. Kada bi se u 2013. godini koristile Klase onda bi se razmjerno uz klasu 5 moglo očekivati tretiranje u klasi 4 , što bi tada ukupno iznosilo 32.850 ha, što bi značilo 6.800 ha odnosno $25 \%$ više u odnosu na novi ovdje predstavljen način obračuna kritičnih brojeva. Ova velika razlika postaje jasna kada se uoči kako stari način obračuna nije uzimao u obzir količinu lista, odnosno veličini krošnje izražene preko starosti stabala. Prema tom obračunu sasvim je bilo svejedno da li je jedno leglo na 30 godišnjem stablu ili na 80 godišnjem, iako je potpuno jasno da starije stablo ima veću krošnju te će trebati više gusjenica (legla) gubara da obrste lišće. Takav jednostavan i grub način dosadašnjeg obračuna predstavlja nepotrebno i veliko rasipanje resursa, stoga se novim načinom obračuna kritičnih brojeva jajnih legala gubara ostvaruju znatne uštede, a razlike su vidljive u navedenim podacima. Jedno moguće objašnjenje zašto se obračun kritičnog broja do sada provodio na taj način leži u tome da precizniji obračuni do sada nisu bili od velike važnosti, budući da pravila primjene insekticida nisu bila stroga, dok se danas isključivo dozvoljava primjena bioloških koji su značajno skuplji. Danas se unos insekticida u ekosustav strože se evaluira s obzirom na njegov utjecaj na ekološku ravnotežu. Sve to dodatno opravdava primjenu novog obračuna, koji bi trebao postati standard u obračunu kritičnih brojeva jajnih legala gubara i planiranja mjera zaštite. Uz vidljive prednosti novog načina obračuna kritičnih brojeva postavlja se i pitanje i njegovog daljnjeg poboljšanja. Pitanje je opravdano kada je poznato da u nekoj sastojine iste starosti vrlo rijetko imamo broj stabala iz normale, a isto tako broj gusjenica u jajnom leglu nije stalan broj. Stoga bi se kritični brojevi za svaku sastojinu trebali korigirati za korekcijski faktor koji bi uzimao u obzir stvarni broj stabla po ha i predvidio obračun broja vitalnih jaja u jajnom leglu gubara. Iako to zahtijeva dodatan napor i može se smatrati nepraktičnim, takav način obračuna bi s obzirom na moguće uštede očekivano trebao biti isplativ. Primjenom modernih tehnologija od satelitskih snimaka i modeliranja vjerojatno bi dale dodatne uštede.

Budući da je 2013 i 2014. na području Petrinje došlo do golobrsta bukve (IPP), buduća istraživanja trebaju precizno izračunati količine lišća koju prosječna gusjenica pojede i odnos prema krošnji za za bukvu. Kada bi bilo poznato koliko lišća ima u određenoj šumi, odluka da li je sastojinu potrebno tretirati insekticidom ili ne, bila bi preciznija, a to bi donijelo očekivano nove uštede.

\section{ZAHVALE}

\section{ACKNOWLEDGEMENTS}

Zahvaljujem se suradnicima iz Zavoda za zaštitu šuma i lovnog gospodarenja na pomoći oko prikupljanju podataka i laboratorijskim analizama: Blaženka Ercegovac, Dinka Matošević, Nikola Lacković, Boris Liović i Ivan Lukić. Također se zahvaljujem kolegama Jasni Molc i Darko Pleskaltu iz poduzeća Hrvatske šume d.o.o. na ustupljenim podacima o suzbijanju gubara u 2013 godini.

Ovo istraživanje djelom je financirano od Hrvatske zaklade za znanost pod projektom DIFPEST (7616).

\section{LITERATURA} REFERENCES

- Dubravac, T., S. Dekanić, B. Vrbek, D. Matošević, V. Roth, T. Jakovljević, T Zlatanov, 2009: Crown volume in forest stands of pedunculate oak and common hornbeam. Periodicum biologorum. 111, 4: 479-485.

- Harapin, M., M. Androić 1996: Sušenje i zaštita šuma hrasta lužnjaka. U: Hrast lužnjak u Hrvatskoj, Ur.: Klepac, D. Hrvatska akademija znanosti i umjetnosti. 227-256.

- Hrašovec, B., M. Harapin, 1999: Dijagnozno-prognozne metode i gradacije značajnih štetnih kukaca u šumama Hrvatske. Šumarski list 5-6: 183-193.

- Klepac, D. 1966: Zuwachsverluste in Eichenmischbestanden, die durch die Kalamitat des Schwammspinners und anderer blattfressender Schadlinge bafallen wurden. Wissenschaftliche Zeitschrift der Technischen Universitat Dresden 15/2:385-389.

- Klepac, D. 1996: Rast i prirast hrasta lužnjaka. U: Hrast lužnjak u Hrvatskoj, ur.: Klepac, D. Hrvatska Akademija znanosti i umjetnosti: 213-226.

- Klepac, D., I. Spaić 1965: Utjecaj nekih defolijatora na debljinski prirast hrasta lužnjaka. Šumarski list (89) 3-4:93-101.

- Lobinger, G., U. Skatulla, 1998: Untersuchungen über Zusammenhänge zwis chen Insektenbefall, Witterungsfaktoren und Eichenschäden in Unterfranken. Bayerisch e Landesanstalt für 
Wald und Forstwirtschaft, Abschlussbericht zum Projekt V 27, Freising, 174 str.

- Moraal, L., J., Hilszczanski 2000: The buprestid beetle, Agrilus biguttatus (F.) (Col., Buprestidae), a recent factor in oak decline in Europe. Journal of Pest Science, 73(5): 134-138.

- Pernek, M., 2001: Gradationen des Schwammspinners in Kroatien von 1970 bis 2000. Mitt. Dtsch. Ges. allg. angew. Ent. 13: 429-432.

- Pernek, M, I. Pilaš 2005: Gradacije gubara - Lymantria dispar L. (Lep., Lymantriidae) u Hrvatskoj. Šumarski list, 5-6: 263-270.

- Pernek, M., Pilaš, I., Vrbek, B., Benko, M., Hrašovec, B., Milković, J., 2008: Forecasting the impact of the Gypsy moth on lowland hardwood forests by analyzing the cyclical pattern of population and climate data series. Forest Ecology \& Management, 255 (5-6): 1740-1748.
- Press, W.H., S.A. Teukolsky, W.T., Vettering, B.P. Flannery 1997: Numerical Recipes, The Art of Scientific Computing. 2. Edition. Cambridge University Press, Chapter 13: 496-536.

- Prpić, B. 1974: Ekološki aspekt sušenja hrastovih sastojina u nizinskim šumama Hrvatske. Šumarski list 98(7/9): 285-290.

- Prpić, B. 1996: Propadanje šuma hrasta lužnjaka. U: Hrast lužnjak u Hrvatskoj, Ur.:Klepac, D. Hrvatska akademija znanosti i umjetnosti. 273-298.

- Spaić, I., 1974: O sušenju hrastika. Šumarski list 98(9):273-284.

- Wulf, A, R. Kehr (ur.) 1996: Eichensterben in Deutschland: Situation, Ursachenforschung und Bewertung. Mitteilungen aus der Bologischen Bundesanstalt fur Land- und Forstwirtschaft 318, Berlin-Dahlem, 157 str.

- Vasić, K. (ur.) 1981: Priručnik izveštajne i dijagnostičko prognozne službe zaštite šuma.Savez inženjera i tehničara šumarstva i industrije za preradu drveta Jugoslavije, Beograd. 336 str.

\section{Summary:}

Gypsy moth, Lymantria dispar was the dominat oak forest pest in Croatia untill 1960s. After this period population particularly in the continental part decreased with cyclical outbreaks every 10-11 years. Last two outbreaks occurred in 2003-2005, and in 2013-2014. In this study a new calculation of critical number of gypsy moth egg masses has been presented in order to estimate the risk of defoliation which is crucial for the decision about application of necessary control measures. The calculation shows critical numbers as number of egg mases per ha which differ from the previous calculations based on number of trees which carry at least 1 egg mass shown in percentages. Hitherto 5 Classes were known out of which the 5 th was critical. This Class presented $50 \%$ of trees which carry at least 1 egg mas and it was assessed as critical. In such calculation the age of the trees was not taken in account although the amount of leaves in the canopy strongly depend on that. Furthermore the number of eggs in the egg masses was also ignored. New calculation is based on numbers of caterpillars which have the potential to defoliate an oak tree of different ages, obtained from literature. The average number of eggs in one egg mass was calculated out of 50 sampled and analysed egg masses. This data together with the normal distribution of oak trees per ha build the basis for the formula. Based on that 3 Categories were formulated which show the potential for defoliation and help to make the decision for applying control measures: Category I - control measures needed; Category II - control measures needed only if there is a special reason; Category III - no control measures needed. Critical numbers of old and new calculation have been compared in years of outbreaks. Results between new and old calculation show $25 \%$ difference which directly means $25 \%$ less area that needs treatment with insecticides. Although the new method has advantages there is still some limitation in the calculation considering that important variables are ignored. The real number of trees per ha and the actual number of intact caterpillars should be used for more accurate calculation and further reduction of forest area that needs protection.

Future research should concentrate on precise calculations of leaf weight consumed by average caterpillar in the relationship to crown volume both for oak and common beech. These values in combination with the number of leaves in the particular forest would make the decisions on use of insecticides more accurate which would bring additional substantial financial savings.

KEY WORDS: population dynamics, pest control, pedunculate oak, Quercus robur 